\title{
REPRODUCTIVE BIOLOGY AND SPATIO-TEMPORAL DISTRIBUTION OF STELLIFER RASTRIFER, STELLIFER NASO AND MACRODON ANCYLODON (SCIAENIDAE) IN THE CAETÉ ESTUARY, NORTHERN BRAZIL
}

\author{
Mauricio Camargo \& Victoria Isaac
}

Universidade Federal do Pará

Laboratório de Biologia Pesqueira e Manejo de Recursos Aquáticos

(Av. Tancredo Neves 2651, 66077-530, Campus Universitário, Belém, PA, Brasil)

e-mails: zorro@ufpa.br; victoria@amazon.com.br

\section{A B S T R A C T}

This study analyses the spatial and temporal distribution of the dominant Sciaenids in the Caeté estuary on the northern coast of Brazil. Samples were taken by otter trawls in four areas of the Caeté estuary between October 1996 and August 1997 six bimonthly. Stellifer rastrifer, Stellifer naso and Macrododon ancylodon presented the highest biomass out of eleven species of Sciaenidae caught. Minimum and mean length at first maturity were calculated and the main spawning periods determined. Changes in the spatio-temporal distribution of the three species were related to seasonal changes in estuarine salinity and spawning pulses. Larvae and juveniles of S. rastrifer, S. naso and $M$. ancylodon were found in the inner estuary while larger specimens were more abundant in the outer estuary with higher salinities. M. ancylodon spawned from October to February and rested from April to August whereas S. rastrifer and S. naso spawned throughout the year, though with two peaks, in October-December and June.

\section{R ESUMO}

\begin{abstract}
O presente estudo caracteriza a distribuição espaço-temporal dos peixes com maior abundância dentre a família Sciaenidae no estuário do rio Caeté, litoral norte do Brasil. Estima-se o comprimento de inicio da maturação sexual, o comprimento médio da primeira maturação sexual e os períodos de desova. Para tal, durante os meses de outubro de 1996 a agosto de 1997, foram feitas 6 coletas bimestrais, através de arrastos de fundo. A partir de subamostras das espécies mais abundantes dentro das capturas, construíram-se distribuições de freqüência de comprimento total, que foram analisadas por período e local de coleta. De onze espécies de Sciaenidae coletadas, a maior contribuição em abundância de exemplares foi feita pelas espécies Stellifer rastrifer, Stellifer naso e Macrodon ancylodon. Determinou-se que a distribuição espacial das espécies no sistema, está relacionada com mudanças periódicas na salinidade dentro do estuário e a sua dinâmica de reprodução. Assim, os juvenis de $S$. rastrifer, S. naso e M. ancylodon distribuíram-se nas áreas mais internas do estuário e os adultos nas águas costeiras, com maiores teores de salinidade. Enquanto que M. ancylodon apresenta desovas periódicas durante outubro a fevereiro, $S$. rastrifer e $S$. naso apresentam desovas parceladas com dois picos mais intensos de outubro a dezembro e durante junho.
\end{abstract}

Descriptors: Sciaenidae, Spatial and temporal distribution, Reproduction, Northern Coast of Brazil, Tropical estuary.

Descritores: Sciaenidae, Distribuição espaço-temporal, Reprodução, Costa norte do Brasil, Estuário tropical.

\section{INTRODUCTION}

Despite the economic importance of the fishery resources in northern Brazil, few studies have been undertaken on their biology, e.g. Barthem (1985) and Sanyo (1998) in the Marajó Bay (Pará) and Fernandes (1982) and Martins-Juras et al. (1987) on São Luís Island (Maranhão).

There is a considerable amount of information available on coastal Sciaenid fish populations of southern Brazilian states (e.g. Vazzoler 
1963, 1965, Yamaguti, 1967, 1968, Martins-Juras 1980, Juras \& Yamaguti, 1985, Haimovici 1988, Kotas 1994, Castro \& Castr,o 1995, Giannini \& Paiva Filho, 1990 and Chaves \& Vende 1997). However, it is still unclear as to whether the knowledge from higher latitudes, i.e., from the subtropical Brazilian coast, on the ecology of widely distributed fish species may be transferred willy-nilly to fish populations inhabiting the tropical, mangrove-dominated northern coast of Brazil, especially in the complex Amazon River estuary. The length at first sexual maturity, spawning ground and spawning seasonal frequency are parameters essential to the understand of the causes of the adults' spatial distributions and the survival rates of the larval fish stages. This study deals with the patterns of spatial and temporal distribution and morphometric parameters of both the juvenile and the adult stages of the Sciaenidae Stellifer rastrifer, Stellifer naso and Macrodon ancylodon in a tropical mangrove estuary in northern Brazil. The comparison of key parameters such as length at first sexual maturity or reproduction dynamics is important to determine similarities between populations along a latitudinal gradient in order to contribute to the preparation of fishery management regulations.

\section{Methods}

The mangrove-dominated estuary of the Caeté River (1570 km²; 4632'16" - 4655'11"W. long. and $00^{\circ} 43^{\prime} 18^{\prime \prime}-00^{\circ} 04^{\prime} 17^{\prime \prime S}$. lat.) is located about 300 $\mathrm{km}$ southeast of the mouth of the Amazon River. In preparation for this study, the Caeté estuary was subdivided into four areas, according to the longitudinal salinity gradient (Fig. 1): A) the main channel of the Caeté River, with low salinity (3 - 15 $\mathrm{ppm})$, extending from Bragança to Caratateua; B) the "bay area" of intermediate salinity $(8-33 \mathrm{ppm})$, as for as the outer estuary bounded by an imaginary line connecting Coroa Comprida Island to the mangrove tidal channel Furo Grande; C) the "coastal area", beyond the Caeté bay as for as the $15 \mathrm{~m}$ isobath line, of higher salinities $(18-36.5 \mathrm{ppm})$; D) "The Furo Grande area" near the bridge connecting Bragança to Ajuruteua, a large macrotidal mangrove channel flowing into the lower Caeté bay.

Six bimonthly samples were taken in the Caeté estuary between October 1996 and August 1997. Samplings took place during the first and third quarter moons, at diurnal neap ebb tides (between 12:00 and 18:00 hours). The 4 areas were sampled twice each month in the first and third quarter moons on two or three consecutive neap tide days.

Fish were collected by 10-15 min trawls with a seine net $(14 \mathrm{~m}$ in width, $50 \mathrm{~mm}$ stretched mesh size/distance between knots at the mouth, $15 \mathrm{~mm}$ at the cod end). Additionally, an over-net $(12 \mathrm{~mm}$ mesh-size stretched mesh size/distance between knots) was put over the cod end to collect juvenile stages. The hands in the main channel of the Caeté River, in the Bay and in the Coastal area were made at placed/located between 3 and $15 \mathrm{~m}$ mean water depth. Three replicate hawls were conducted in each area. In each sample month, the same three replicate sample sites were trawled, recognized by their GPS positions. For each hawl, water depth (m) and Secchi depth (m) were measured. Temperature $\left({ }^{\circ} \mathrm{C}\right)$, salinity and dissolved oxygen $(\mathrm{mg} / \mathrm{L})$ were recorded at the water surface. Distances between fishing ships, and the length of the loose cable varied between $15 \mathrm{~m}$ and 30 $\mathrm{m}$, depending on the mean water depth of a hawl. Global Positioning System (GPS) positions were recorded at the beginning and end of each hawl to calculate the distance trawled. Each hawl's the total catch weight $(\mathrm{g})$ was recorded. The fish were placed in plastic bags and preserved on ice. In the laboratory the fish were identified to the species level in accordance with Chao (1978) and Cervigón et al. (1992). For each species, the number of specimens and their total wet weight $(\mathrm{g})$ were recorded by sample area. Sub-samples were created within the 21,577 Sciaenidae collected, in order to build $1 \mathrm{~cm}$-length class frequencies. Ten specimens of each $1 \mathrm{~cm}$-length class were measured for total length and wet weight $( \pm 0.01 \mathrm{~g})$. Each specimen of a sub-sample was sexed.

Sexual maturity was classified into five categories in accordance with Vazzoler (1996): immature, developing, spawning, spent - recovering in recuperation, and resting.

Thus, 1086 specimens were divided into 469 of M. ancylodon, 459 of Stellifer rastrifer and 158 of Stellifer naso.

The gonads were then extracted and wet weighed $( \pm 0.00001 \mathrm{~g})$. The gonosomatic index $(G S I)$ was calculated as:

$$
G S I=\frac{W_{g}}{W_{t}} \times 100
$$

where:

$W_{g}=$ gonad wet weight $(\mathrm{g})$

$W_{t}=$ total weight of each specimen $(\mathrm{g})$ minus weight of gonads $(\mathrm{g})$

The spawning period of each species was determined using GSI values and the abundance of ripe individuals. To separate adults from juveniles, a first estimate of the mean length at first sexual maturity $\left(L_{\text {min }}\right)$ for both male and females was plotted against the mean GSI. 


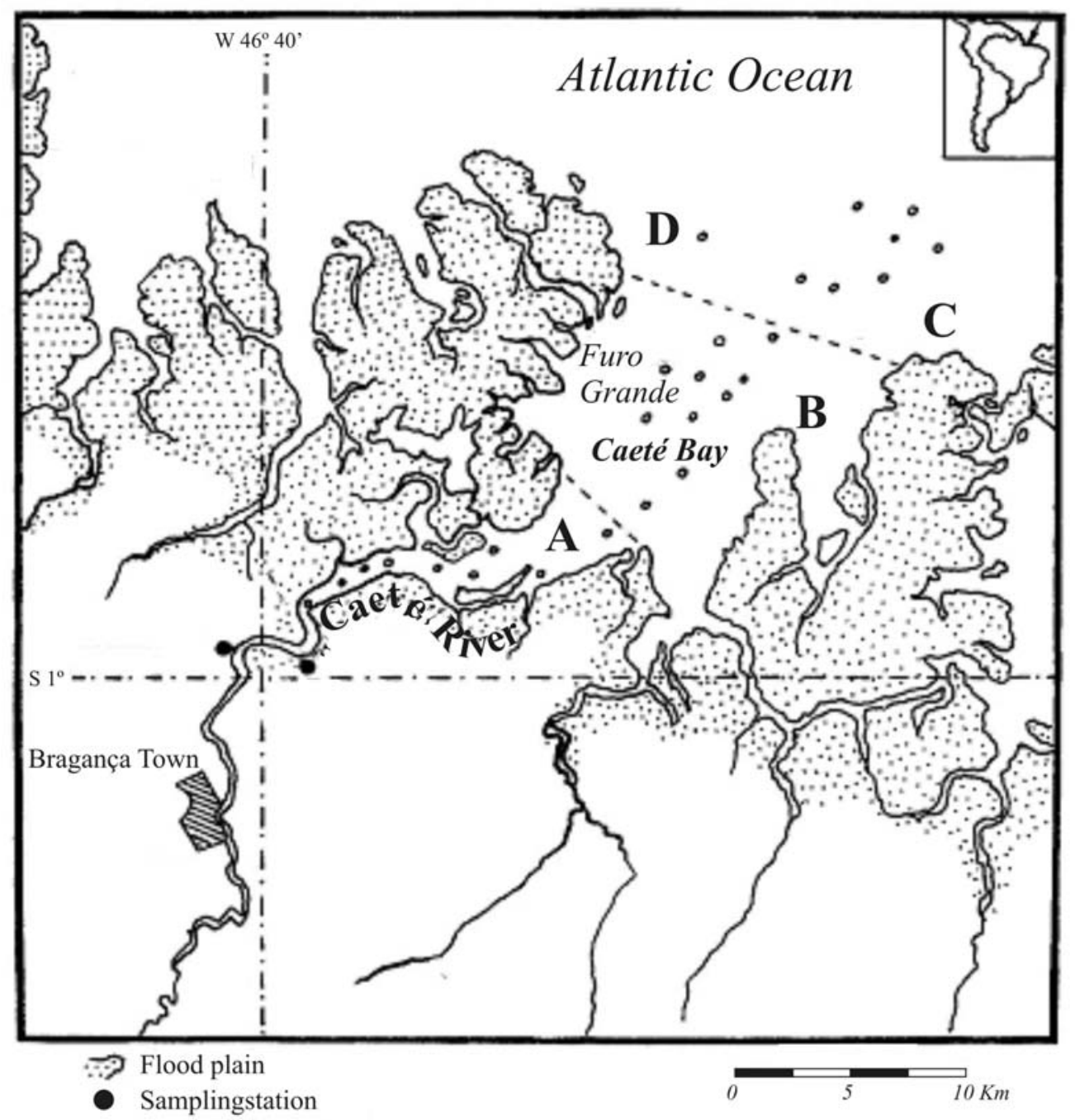

Fig. 1. Caeté Estuary - Northern littoral of Brazil (Mean salinity: $A=3-15 p p m, B=8-33 p p m, C, D=18-36.5 p p m)$.

The $L_{50}$ logistic curves were adjusted using the equation proposed by King (1996).:

$$
P=1 /\left(1+E X P\left[-r\left(L-L_{50}\right)\right]\right)
$$

where:

$P=$ proportion of adults

$r=$ logistic curve constant, and

$L_{50}=$ average length at first sexual maturity.

After the calculation of proportion of adults $(P)$ and exclusion of extreme values (close to 0 or 1 ), the $\ln (1-P / P)$ was calculated and adjusted to a linear regression in which $x$ was equivalent to TL and $y$ to $\ln (1-P / P)$. The corresponding linear equation was established by the least squares method. The parameters $a$ and $b$ were calculated and used to define $r$ and $L_{50}$, with $r=(-b)$ and $L_{50}=a / r$.

Based on the $L_{\min }$ and the logistic curve adjusted for each species, the juvenile and adult lengths were established. The proportions of adults and juveniles were calculated for each sample area. A factor analysis was applied. The new factors were related to the environmental variables using ANCOVA (Sokal \& Rohlf, 1997). 


\section{Results}

The Caeté estuary is characterized by seasonal changes in the longitudinal salinity gradient. During April to July 1997 (rainy season), the mean salinity of the entire estuarine system had decreased dramatically. In June, the mean salinity on the coast was 22.2 In the dry season (August to December) the salinity increased to a value of 31.6. Mean salinity in the main channel was 7.3 (rainy season) and 18.5 (dry season) (Fig. 2).

The water temperature was usually between $27^{\circ} \mathrm{C}$ and $29^{\circ} \mathrm{C}$, but a minimum of $23^{\circ} \mathrm{C}$ and a maximum of $31^{\circ} \mathrm{C}$ occurred in April and December, respectively. The mean water temperatures throughout the estuary were most similar during the dry season (Fig. 3).

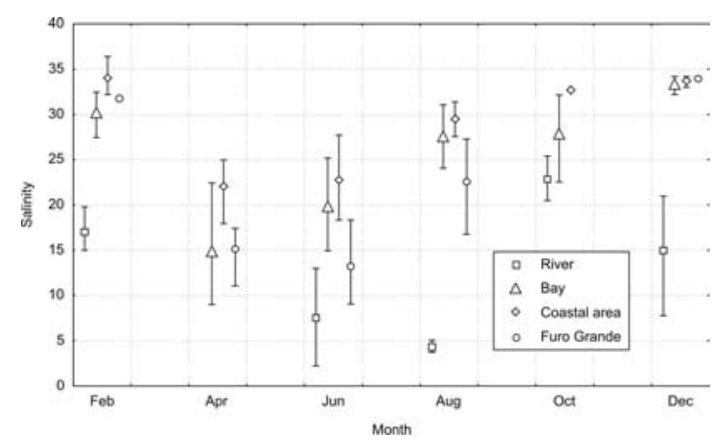

Fig. 2. Mean monthly salinity by environment in the Caeté Estuary.

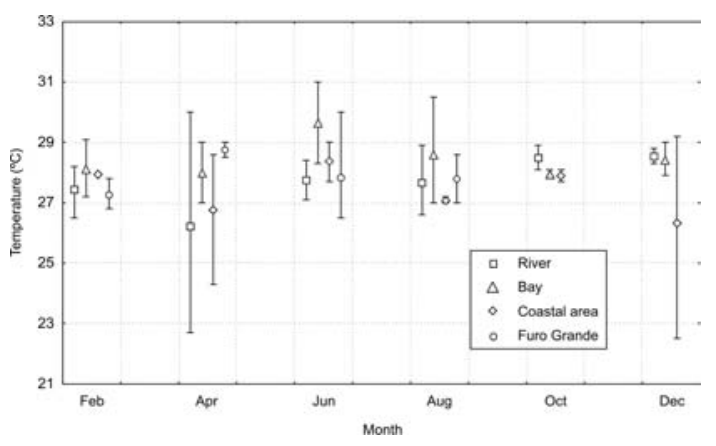

Fig. 3. Mean monthly temperature $\left({ }^{\circ} \mathrm{C}\right)$ by environment in the Caeté Estuary.

The mean fish biomass of all fish in the catches was $2.75 \mathrm{~g} / \mathrm{m}^{2} \pm 4.80 \mathrm{~g} / \mathrm{m}^{2}$ (IC 95\%) and ranged from $0.01 \mathrm{~g} / \mathrm{m}^{2}$ to $23.69 \mathrm{~g} / \mathrm{m}^{2}$. For the entire Estuary, the total mean biomass showed a decreasing pattern, in the inshore-offshore direction accompanying an increasing salinity gradient. Eleven Sciaenidae species were recorded in the Caeté estuary. The main biomass and frequency of occurrence was determined for the three most abundant species: Stellifer rastrifer, Stellifer naso and Macrodon ancylodon (Tab. 1).

\section{Spatial Distribution}

Juveniles of all three species were more abundant in the inner estuary; adults were more abundant in the outer estuarine and coastal area. During the rainy season the juveniles occurred further downstream. During the dry season the adults moved towards the river after the seasonal increase in the estuarine salinities.

Table 1. Species biomass of the dominant Sciaenids in the Caeté estuary, northern coast of Brazil.

\begin{tabular}{|c|c|c|c|c|c|c|c|c|}
\hline \multirow[b]{3}{*}{ Month } & \multicolumn{8}{|c|}{ CPUA $\left(\mathrm{g} / \mathrm{m}^{2}\right)$} \\
\hline & & & & $\%$ & & $\%$ & & $\%$ \\
\hline & Area & Sciaenidae & M. ancylodon & Sciaenidae & S. rastrifer & Sciaenidae & S. naso & Sciaenidae \\
\hline \multirow{4}{*}{ Oct. 96} & A & 0.50 & 0.096 & 19.21 & 0.375 & 75.01 & 0.000 & 0.07 \\
\hline & $\mathrm{B}$ & 0.20 & 0.108 & 54.03 & 0.062 & 31.00 & 0.008 & 3.99 \\
\hline & $\mathrm{C}$ & 0.83 & 0.483 & 58.18 & 0.340 & 40.92 & 0.007 & 0.90 \\
\hline & A & 0.54 & 0.017 & 3.19 & 0.451 & 83.45 & 0.049 & 9.08 \\
\hline \multirow[t]{2}{*}{ Dec. 96} & B & 0.35 & 0.062 & 17.64 & 0.252 & 71.88 & 0.003 & 0.77 \\
\hline & $\mathrm{C}$ & 1.65 & 0.928 & 56.24 & 0.639 & 38.73 & 0.000 & 0.00 \\
\hline \multirow{4}{*}{ Feb. 97} & A & 0.99 & 0.519 & 52.40 & 0.387 & 39.11 & 0.014 & 1.45 \\
\hline & $\mathrm{B}$ & 1.64 & 0.248 & 15.15 & 1.380 & 84.12 & 0.000 & 0.00 \\
\hline & $\mathrm{C}$ & 0.62 & 0.128 & 20.60 & 0.479 & 77.19 & 0.000 & 0.00 \\
\hline & A & 0.15 & 0.027 & 18.12 & 0.119 & 79.33 & 0.004 & 2.56 \\
\hline \multirow[t]{2}{*}{ Apr. 97} & B & 1.79 & 0.514 & 28.70 & 1.130 & 63.11 & 0.133 & 7.43 \\
\hline & $\mathrm{C}$ & 0.02 & 0.000 & 0.00 & 0.000 & 0.00 & 0.017 & 86.54 \\
\hline \multirow{3}{*}{ Jun. 97} & A & 1.57 & 0.125 & 7.97 & 1.358 & 86.49 & 0.077 & 4.92 \\
\hline & B & 1.86 & 1.266 & 68.04 & 0.425 & 22.87 & 0.006 & 0.32 \\
\hline & $\mathrm{C}$ & 0.41 & 0.195 & 47.66 & 0.189 & 46.05 & 0.019 & 4.55 \\
\hline \multirow{3}{*}{ Aug. 97} & A & 1.00 & 0.073 & 7.30 & 0.801 & 80.12 & 0.112 & 11.20 \\
\hline & B & 0.01 & 0.000 & 0.00 & 0.008 & 83.02 & 0.002 & 16.98 \\
\hline & $\mathrm{C}$ & 0.05 & 0.003 & 5.10 & 0.047 & 94.18 & 0.000 & 0.00 \\
\hline
\end{tabular}




\section{Species Level:}

The spatial estuarine distribution of Macrodon ancylodon varied according to the ontogenetic stages. In August (transition al from rainy to dry), juveniles were more abundant upstream in the river while adults were more common in the Furo Grande tidal channel. From February to June (rainy season) both juveniles and adults occurred together in the Bay. From October to December (dry season) the adults occurred together with the juveniles in the coastal area and invaded the bay waters (Figs 4A, B).
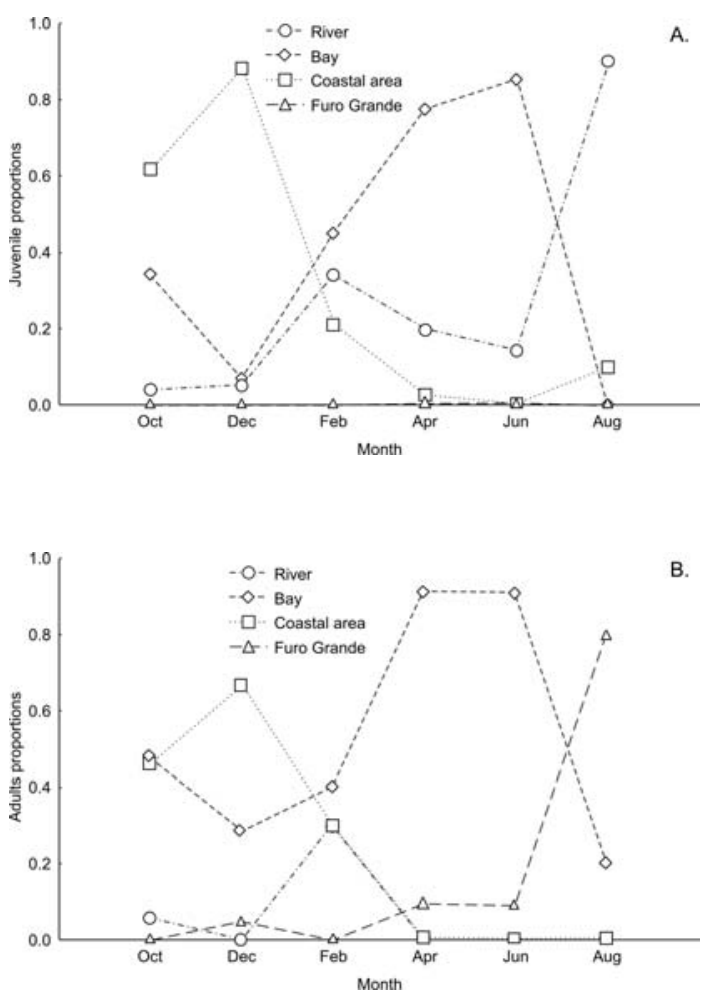

Fig. 4. Juvenile (A) and adult (B) proportions of Macrodon ancylodon by month and estuarine environment.

Juveniles and adults of Stellifer rastrifer were also separated spatially. In October (dry season) juveniles were found both in the bay and in the river (Fig. 5A); adults were more abundant in the bay in December and April, when the estuary presented saltier waters (Fig. 5B).
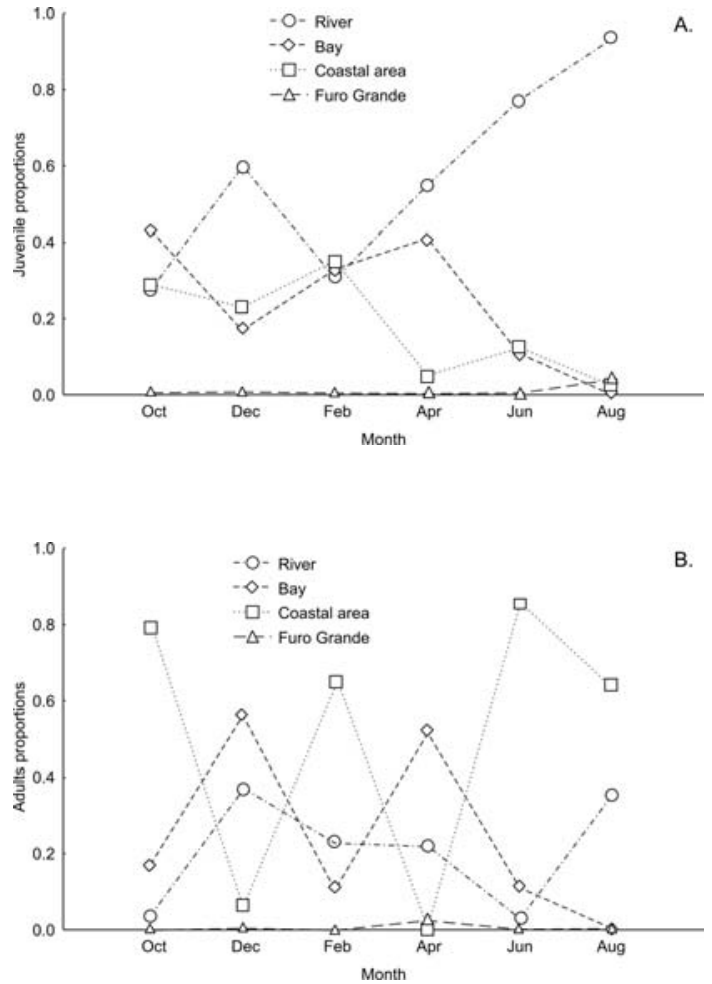

Fig. 5. Juvenile (A) and adult (B) proportions of Stellifer rastrifer, by month and estuarine environment.

The spatial-temporal distribution pattern of juvenile Stellifer naso was similar to that of Stellifer rastrifer juveniles, except in April, when the former inhabit mainly the coastal area, differently from the rest of the year (Fig. 6A). The larger proportion of adults was recorded in February in the coastal area, and in the Furo Grande in April, October and December (Fig. 6B).

Factor analyses relating abundance of juveniles and adults of the three Sciaenidae species indicated: 1) a strong positive association between juveniles of Stellifer naso and those of Stellifer rastrifer and 2) a positive correlation between adults of $S$. rastrifer and both juveniles and adults of Macrodon ancylodon (Tab. 2). The two factors accounted for $52 \%$ and $47 \%$ of the total variability respectively, of the data. Analysis of covariance did not indicate any statistically significant differences in the spatial and temporal distribution of abundance and biomass with regard to the environment on seasonal periods. 

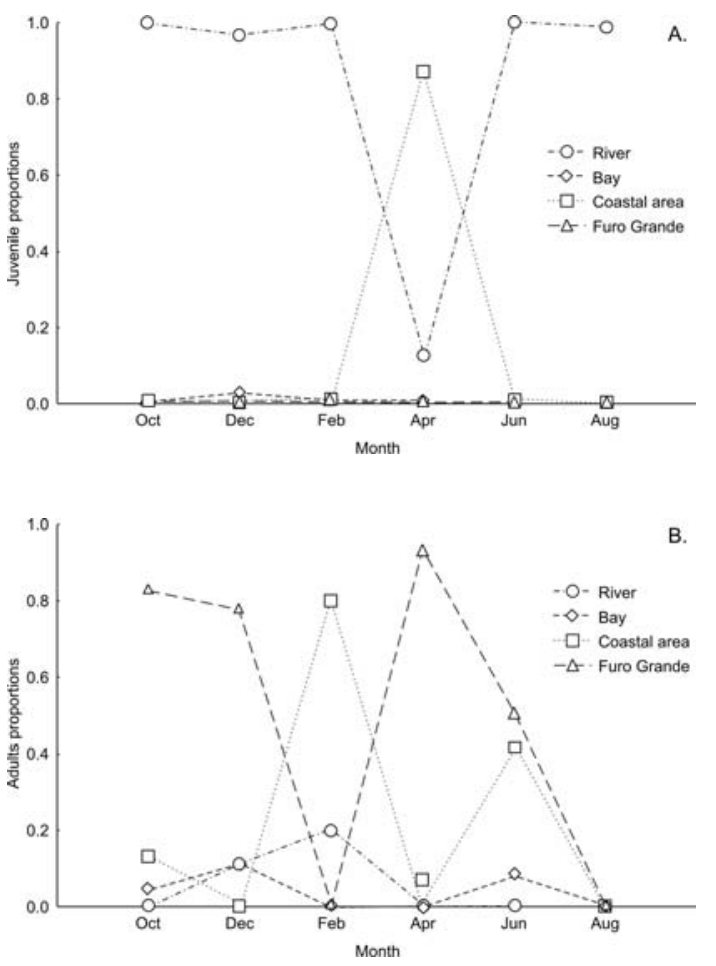

Fig. 6. Juvenile (A) and adult (B) proportions of Stellifer naso, by month and estuarine environment.

Table 2. Factor analysis of the juvenile and adult proportions of Stellifer rastrifer, Macrodon ancylodon and Stellifer naso.

\begin{tabular}{lcc}
\hline \hline \multicolumn{1}{c}{ Association } & Factor 1 & Factor 2 \\
\hline Juveniles $S$. rastrifer & $\mathbf{0 , 9 4 9 0}$ & $-0,1721$ \\
Adults $S$. rastrifer & $-0,1004$ & $\mathbf{- 0 , 7 2 6 5}$ \\
Juveniles $M$. ancylodon & 0,3290 & $\mathbf{- 0 , 6 3 5 7}$ \\
Adults $M$. ancylodon & $-0,3235$ & $\mathbf{- 0 , 8 3 1 2}$ \\
Juveniles $S$. naso & $\mathbf{0 , 9 0 5 3}$ & 0,1862 \\
Adults $S$. naso & $-0,3227$ & 0,4233 \\
Explanatory variable. $(\%)$ & 52 & 47 \\
\hline
\end{tabular}

\section{Sexual Maturity and Spawning Periodicity}

Macrodon ancylodon had a maximum length of $41 \mathrm{~cm}$ and a first sexual maturity $\left(L_{\mathrm{min}}\right)$ of $17.7 \mathrm{~cm}$ and $L_{50}$ of $22.1 \mathrm{~cm}$, Stellifer naso had of maximum length 25 $\mathrm{cm}$, of $L_{\min }$ of $9.5 \mathrm{~cm}$ and $L_{50}$ of $12.1 \mathrm{~cm}$. Finally, Stellifer rastrifer presented a maximum length of $17 \mathrm{~cm}$, and began its sexual maturity with $L_{\min }$ of $9.5 \mathrm{~cm}$, and $L_{50}$ of $11.7 \mathrm{~cm}$.

The three species exhibited different reproductive dynamics. Macrodon ancylodon is a periodic spawner, spawning from October to February, and resting from April to August (Fig. 7A). Stellifer rastrifer and Stellifer naso were continuous spawners throughout the year
(Figs 7B, 7C). However, there wa s a spawning pulse from October to December and a second one in June, the latter being more pronounced in Stellifer rastrifer.

The females of Stellifer rastrifer presented a lower mean gonad somatic index than the other two species $(2.18 \pm 1.79$ 95\% CI); Stellifer naso presented values of $7.05 \pm 0.31$ and Macrodon ancylodon of $6.56 \pm 0.11$ (Fig. 7).
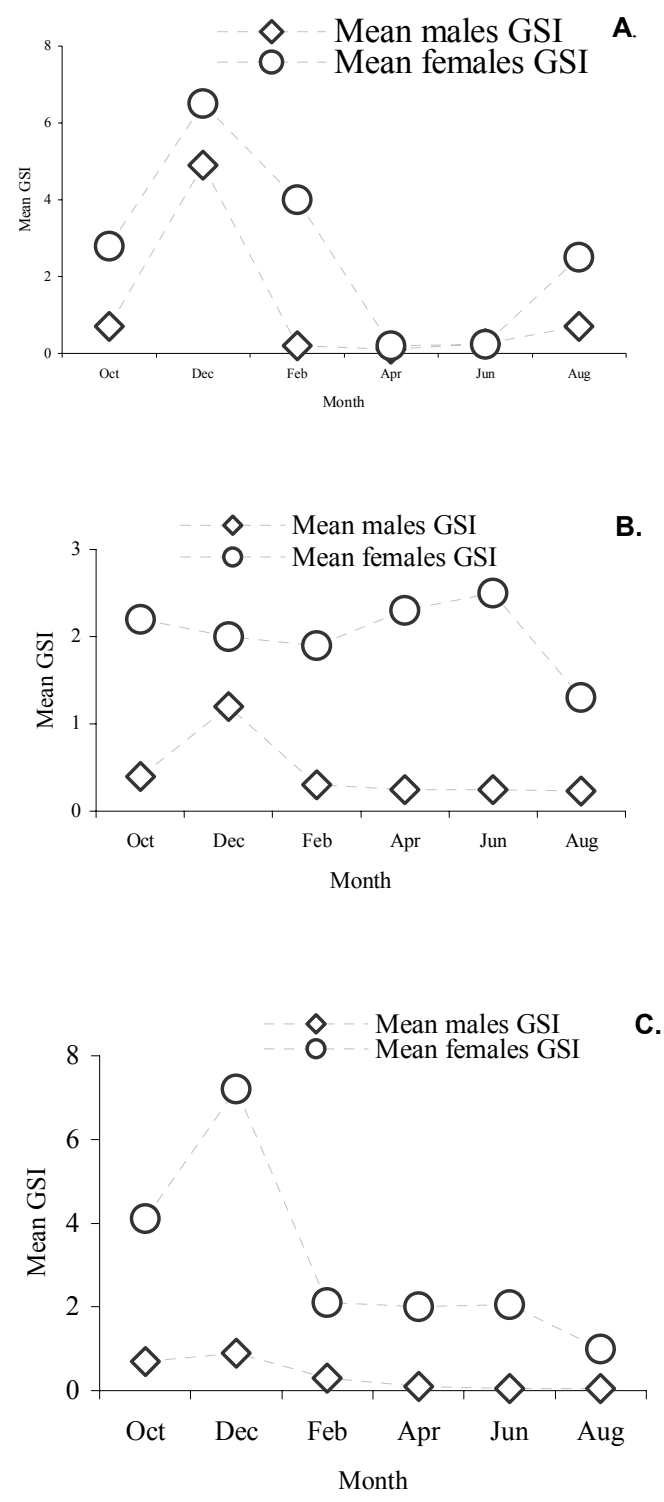

Fig. 7. Monthly gonadosomatic index by sex: (A) Macrodon ancylodon, (B) Stellifer rastrifer, (C) Stellifer naso. 


\section{Discussion}

The Caeté estuary is one of about three largersized estuaries characterizing the second largest mangrove area of the worl, along the Para and Maranhão coastline (Kjerfve \& Lacerda, 1993). The tropical coastal ecosystems are characterized by a welldefined alternation between a rainy and a dry season. This results from the very low precipitation, when salt water enters the estuary because the freshwater inflow is small. The distribution of adults and juveniles was found to be related to the seasonal salinity fluctuations occurring in the estuarine system.

An inshore movement of adults of all three species in a spawning condition observed during the months of high salinity showed this to be a breeding area. Larvae born at that time of the year would develop in relatively salty waters, necessary for their metabolic requirements (Barletta-Bergan, et al., 2002). These patterns also indicate lower adult osmoregulation tolerance to changes in water salinity, as compared to the first juvenile stages which initially inhabit the fresh waters and afterwards move to saltier waters as they are developing (Figs 8A, B). The reproduction pulses for the Macrodon ancylodon of the Caeté estuary were closely synchronized with those recorded for estuarine areas in French (Puyo, 1949) and British (LoweMcConnell, 1966; Hackett et al., 2000) Guyana. This beings out the faet that there is only one stock with a wide geographical distribution along the north-eastern coast of South America. Further evidence for a single stock is provided by the DNA analysis, which indicated the existence of two species of Macrodon along the South America coast, one extending from Venezuela to the northeastern coast of Brazil and the other to the Southeast (Santos et al., 2003).

The reproduction pattern found for Stellifer rastrifer agreed with that observed for the estuarine areas of Venezuela (Lowe-McConnell, 1966).

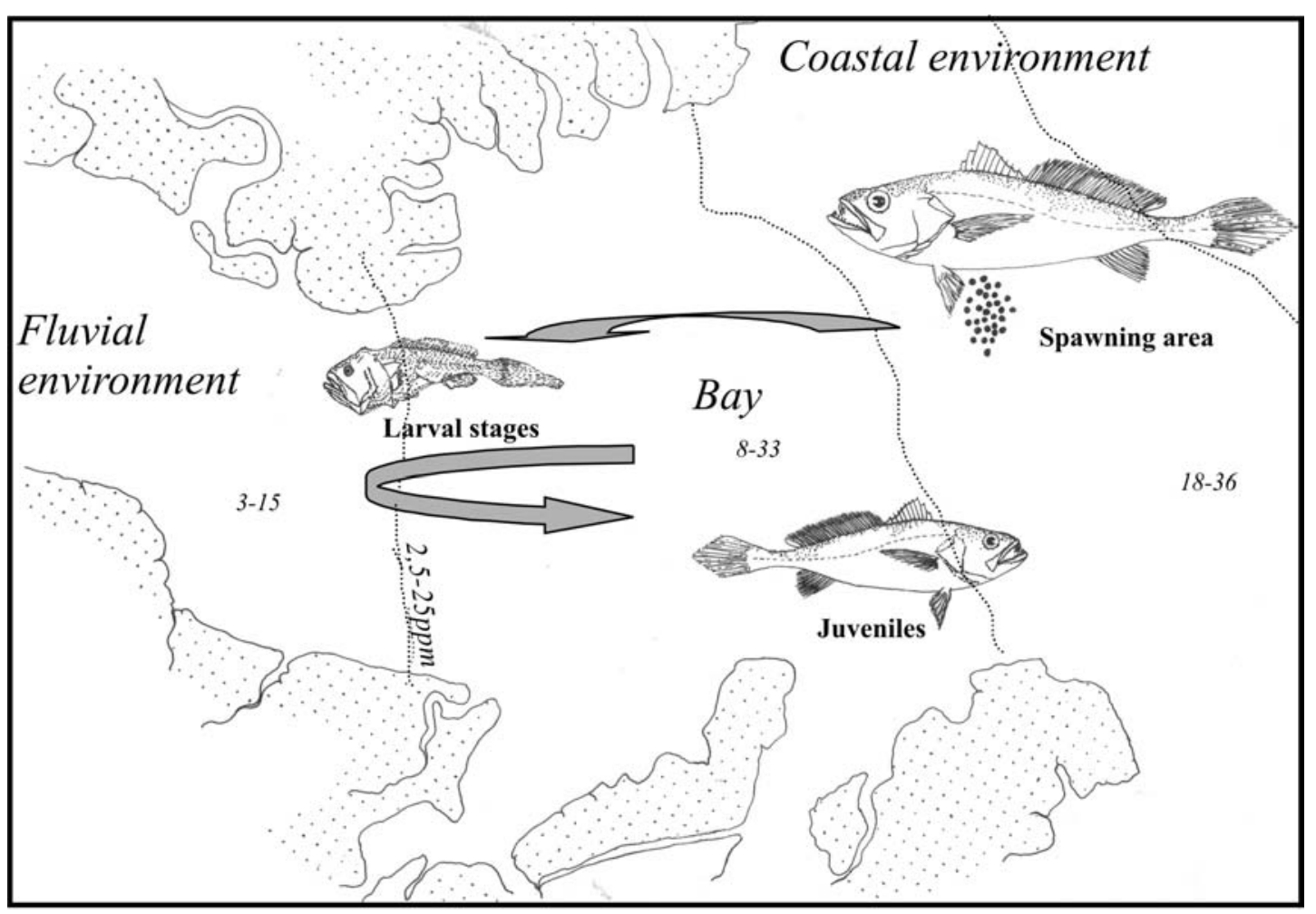

Fig. 8A. Spatial distribution of Macrodon ancylodon. 


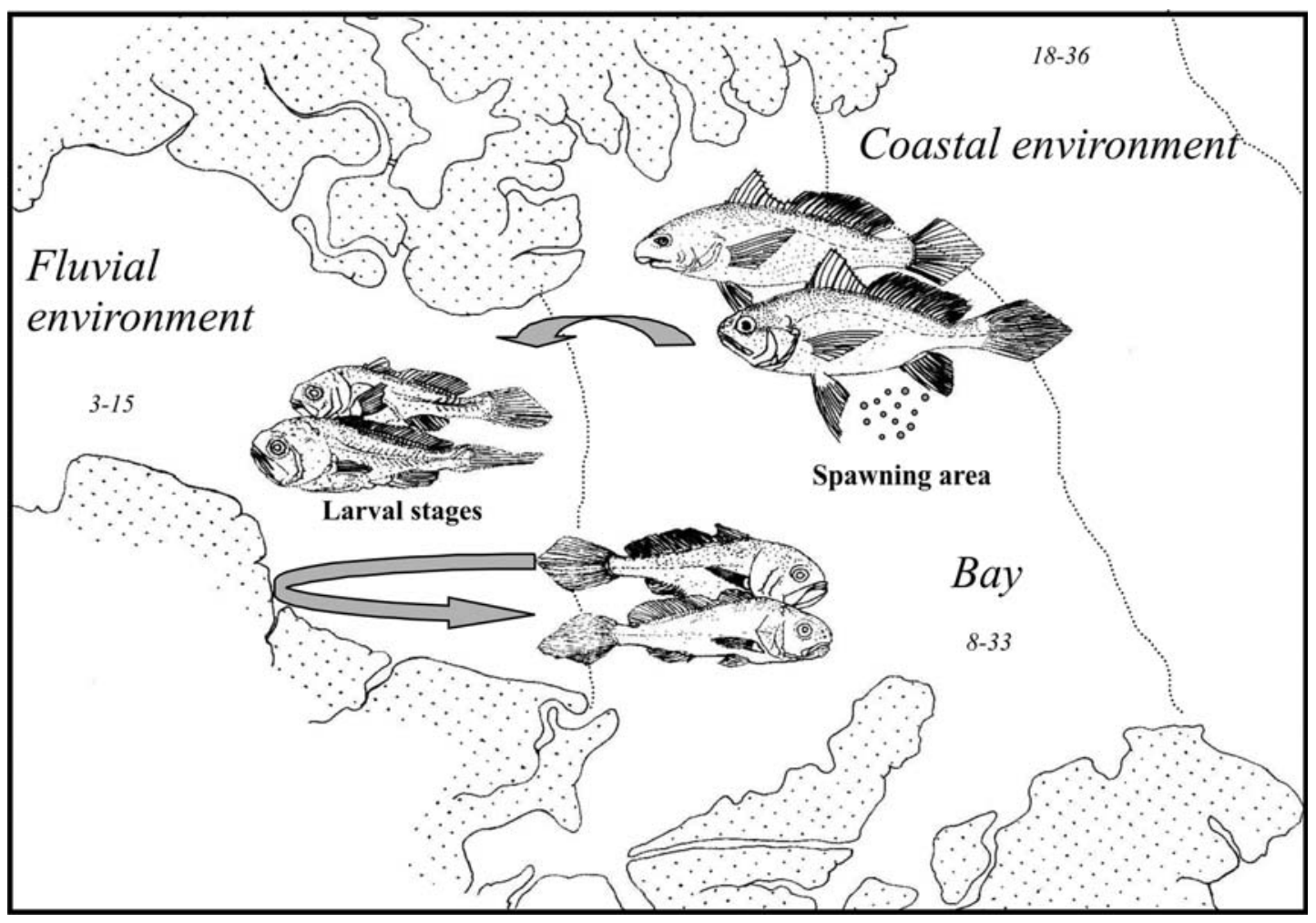

Fig. 8B. Stellifer rastrifer and S. naso, in the Caeté Estuary.

\section{REFERENCES}

Barletta-Bergan, A.; Barletta, M. \& Saint-Paul, U. 2002. Structure and Seasonal Dynamics of Larval Fish in the Caeté River Estuary in North Brazil. Estuar. coast. Shelf Sci. 54:193-206.

Barthem, B. R. 1985. Ocorrência, distribuição e biologia dos peixes da Baía de Marajó, Estuário Amazônico. Bol. Mus. Para. Emílio Goeldi, ser. Zool., 2(1):49-69.

Castro, L. A. B. de \& Castro, P. M. G. 1995. Variação do comprimento médio da pescada foguete Macrodon ancylodon, capturada na região Sudeste do Brasil $23^{\circ}$ a $29^{\circ} \mathrm{S}$ desembarcada em Santos, de 1976 a 1990. Publção esp. Inst. Oceanogr., S Paulo, 11:187-196.

Cervigón, F. R.; Cipriani, W.; Fisher, L.; Garibaldi, M.; Hnedrickx, A. J.; Márques, R.; Poutiers, J. M.; Robaina, G. \& Rodriguez, B. 1992. Guia de campo de las especies comerciales marinas y de aguas salobres de la costa septentrional de Sur América. Roma, FAO. 513p.

Chao, L. N. 1978. A basis for classifying western Atlantic Sciaenidae (Teleostei, Perciformes). NOAA Tech. Rept, NMFS Tec. Circ., (415):1-64.

Chaves, P. de T. C. \& Vende, A. L. 1. 1997. Reprodução de Stellifer rastrifer (Jordan) (Teleostei, Sciaenidae) na Baía de Guaratuba, Paraná, Brasil. Revta. Bras. Zool., Curitiba, 14(1):81-90.
Fernandes, G. 1982. Estudo da alimentação da "Corvina Boca-Mole", Macrodon ancylodon (Bloch \& Scheider, 1801) Teleostei, Sciaenidae, na Ilha de São LuísMaranhão. Bol. Lab. Hidrob., São Luís, 4(1):51-64.

Giannini, R. \& Paiva-Filho, A. M. 1990. Aspectos bioecológicos de Stellifer rastrifer (Perciformes: Sciaenidae) na Baía de Santos, SP. Bolm Inst. oceanogr., S Paulo, 38(1):57-67.

Hackett, A.; Cochrane, K. \& Booth, A. 2000. Assessments of Fisheries in Guyana for Bangamary (Macrodon ancylodon) and butterfish (Nebris microps). In: Report of the Third workshop on the assessment of shrimp and groundfish fisheries on the Brazil-Guianas Shelf. Roma, FAO Fisheries Report, 628:110-123.

Haimovici, M. 1988. Crescimento de la pescadilla real (Macrodon ancylodon) en el sur del Brasil en el periodo de 1984-1986. Publicación científica de la Comisión Mixta de Frente Marítimo, Montevideo, 4:99-106.

Juras, A. \& Yamaguti, N. 1985. Food and Feeding habits of King weakfish Macrodon ancylodon (Bloch \& Schneider, 1801) caught in the southern coast of Brazil (Lat. $29^{\circ}$ to $32^{\circ} \mathrm{S}$ ). Bolm Inst. oceanogr., S Paulo, 33:149-157.

Kjerfve, B. \& Lacerda, L. D. 1993. Mangroves of Brazil. In: de Lacerda, L.D. (Ed.) Mangrove ecosystems technical reports. ITTO TS-13:245-272.

King, M. 1996. Fisheries biology, assessment and management. Oxford, Fishing News Books. 341p. 
Kotas, J. E. 1994. Avaliação do estoque da pescadinha Macrodon ancylodon, (Block \& Schneider, 1801) da Costa do Rio Grande do Sul, entre os anos de 1986-1989. Amazonas, Ministério do Médio Ambiente da Amazônia Legal - MMAA. 27p.

Lowe-McConnell, R. H. 1966. The Sciaenid Fishes of Bristish Guiana. Bull. mar. Sci., 16(1):1-57.

Martins-Juras, I. A. G. 1980. Estudo sobre o crescimento de Macrodon ancylodon (Bloch \& Schneider, 1801) capturada nas costas do Rio Grande do Sul (Latitude $29^{\circ} \mathrm{S}$ a $\left.32^{\circ} \mathrm{S}\right)$. Bolm Inst. oceanogr., S Paulo, 29(2):197199.

Martins-Juras, I. A. G. M.; Juras, A. A. \& Menezes, N. A. 1987. Relação preliminar dos peixes da ilha de São Luís - MA, Brasil. Revta. Bras. Zool., 4(2):105-113.

Puyo, J. 1949. Poissons de la Guyane Française. Faune de l'Empire Français. Paris, Rech. Sci. Outre-Mer, 280 p.

Santos, S.; Schneider, H. \& Sampaio, I. 2003. Genetic differentiation of Macrodon ancylodon (Sciaenidae, Perciformes) populations in Atlantic coastal waters of South America as revealed by mtDNA analysis. Genet. Mol. Biol., 26(2):151-161.

Sanyo Techno Marine. 1998. Draft final report for the fishery resources study of the Amazon and Tocantins river mouth areas in the Federative Republic of Brazil. Belém. $334 \mathrm{p}$.
Sokal, R. R. \& Rohlf, F. J. 1997. Biometry. The principles and practice of statistics in biological research, third ed. New York, W.H. Freeman and Co. 887p.

Yamaguti, N. 1967. Desova da pescada-foguete, Macrodon ancylodon. Bolm Inst. oceanogr., S Paulo, 16(1):101106.

Yamaguti, N. 1968. Mortalidade da pescada foguete, Macrodon ancylodon. Bolm Inst. oceanogr., S Paulo, 17(único):67-70.

Vazzoler, A. E. 1963. Sobre a fecundidade e desova da pescada foguete. Bolm Inst. oceanogr., S Paulo, 13(2):33-40.

Vazzoler, A. E. 1965. Relative spawning power of Macrodon ancylodon (Bloch) population in the southern coast of Brazil. Anais Acad. Bras. Ciênc., 37(supl.):365-370.

Vazzoler, A. E. 1996. Biologia da reprodução de peixes Teleosteos: Teoria e prática. Maringá, Edum-Nupelia. $169 \mathrm{p}$.

(Manuscript received 20 October 2004: revised 06 June 2005; accepted 20 August 2005) 